\title{
A Dynamic Correlation Analysis of Financial Contagion: Evidence from the Eurozone Stock Markets
}

\author{
Mohamed Ali Trabelsi, Salma Hmida
}

\begin{abstract}
A B S T R A C T
Objective: In this article, we try to determine whether there are contagion effects across the Greek stock market and the Belgian, French, Portuguese, Irish, Italian and Spanish stock markets during both crises periods.

Research Design \& Methods: To reach our aim, we used a bivariate Dynamic Conditional Correlation-Generalized Autoregressive Conditional Heteroscedasticity (DCC-GARCH) model to measure the extent of dynamic correlations between stock returns of our sample.
\end{abstract}

Findings: Our results point to the presence of a contagion effect between all market pairs during the subprime crisis and between the Greek and Portuguese stock markets during the European sovereign debt crisis.

Implications \& Recommendations: The obtained results are useful for investors, in particular for their portfolio diversification strategies. They are also useful for the monetary and financial authorities in their efforts to absorb shocks resulting from crises.

Contribution \& Value Added: The originality of this work lies in studying contagion effect across the Eurozone stock markets through the bivariate DCC-GARCH model which is an original dynamic estimation of conditional correlations in Multivariate GARCH models. The measures of contagion effects following the valuation of countries induced by the massive negative sovereign rating signals during the crisis period would also be interesting to study. The methods might also be applicable to this kind of contagion type and for contagions effects across European stock market returns.

\section{Article type: research paper}

Keywords:

Eurozone; Financial contagion; European debt crisis; Sovereign risk;

JEL codes:

Dynamic conditional correlations; interdependence

Received: 20 March 2018 Revised: 22 August 2018 Accepted: 30 August 2018

\section{Suggested citation:}

Trabelsi, M.A., \& Hmida, S. (2018). A Dynamic Correlation Analysis of Financial Contagion: Evidence from the Eurozone Stock Markets. Entrepreneurial Business and Economics Review, 6(3), 129-141. https://doi.org/10.15678/EBER.2018.060308 


\section{INTRODUCTION}

The turmoil that has characterised capital markets since the summer of 2007 and its intensification since mid-September 2008 have had a serious impact on the global economy. Although the US high-risk mortgage market is considered to be the immediate cause of this turmoil, in recent years the Eurozone capital markets and financial institutions have taken their share of the extended credit cycle and have been hit hard by capital markets tensions (Trabelsi, 2012).

The euro sovereign debt crisis finds its origin in Greece (Papavassiliou, 2014; Ray, 2015; Smeets, 2016). After disclosing the Greek deficit, leading to an increase in sovereign risk perception, the Greek crisis has spread to the most fragile Eurozone member countries (Ehrmann \& Fratzscher, 2016). As a result, uncertainties about the Eurozone markets and the unpredictable nature of the European debt crisis have seriously undermined investor sentiment.

On the other hand, the successive and massive credit rating downgrading of several Eurozone countries, in particular the most fragile ones, led to markets over-reacting to the bad news (Arezki et al., 2011). In the wake of the crisis, the Eurozone stock markets experienced massive depreciations coupled with high stock market volatility. Taking into account these turbulences, it seems therefore necessary to determine the extent of interdependence between the Eurozone stock markets and to examine whether there is a contagion relationship between these markets during the crises periods. Studying financial contagion effects across the Eurozone stock markets is very interesting because these markets are strongly integrated as suggested by several authors (Fratzscher, 2002, Bartram et al., 2007). Indeed, due to the factors relating countries through trade and the banking sector, we should expect higher interdependence and contagion levels, both between and within the Eurozone markets and other countries' markets. Moreover, several authors like Savva (2009) and Connor and Suurlaht (2013) have pointed to an increasing correlation between European stock markets after introducing the Euro.

In this regard, in order to gather evidence about any contagion phenomenon across the Eurozone stock markets, we refer to the non-contingent crises theory where contagion is but a continuation of the interdependence process between markets (Forbes \& Rigobon, 2002). We therefore examine the co-movements between the Greek stock market, as the market generating the debt crisis, and six Eurozone stock markets. For that, we will use the DCC-GARCH model proposed by Engle and Sheppard (2001), Engle (2002) and Tse and Tsui (2002). This model is an original dynamic estimation of conditional correlations in Multivariate GARCH models. The innovation of multivariate GARCH models allows to produce timevarying correlation coefficients and energised interest in financial contagion studies.

This article is then structured as follows. Section 1 reviews relevant theoretical and empirical literature. Section 2 presents our research methodology. Section 3 presents our econometric model and the main results. The final section discusses our findings.

\section{LITERATURE REVIEW}

Several theoretical and empirical studies have focused on contagion (Bekaert, Ehrmann, Fratzscher, \& Mehl, 2014). However, research on contagion during the European sovereign debt crisis using correlation analyses shows mixed results. Indeed, some studies 
found a significant increase in the correlation coefficients between the different financial markets returns during the European debt crisis (Claeys \& Vasicek, 2014; Kalbaska \& Gatkowski, 2012; Metiu, 2012; Missio \& Watzka, 2011; Andenmatten \& Brill, 2011). Other researchers believe that correlations between financial markets did not show an upward trend during the same period, suggesting the presence of a simple interdependence rather than contagion (Caporin, Pelizzon, Ravazzolo, \& Rigobon, 2013; Briere, Chapelle, \& Szafarz, 2012). Samitas and Tsakalos (2013) examined the relationship between the Greek stock market and seven European stock markets using an asymmetric DCC model and copula functions to measure financial contagion. Their results point to the presence of a contagion phenomenon during the subprime crisis and reject the presence of this phenomenon during the European sovereign debt crisis. In his paper on financial contagion during the sovereign crisis, Horta (2012) suggests that the stock markets of the NYSE Euronext group, whose sovereign debt is not under market pressure, do not show contagion signs unlike at-risk countries, which showed the most serious debt problems with contagion signs. This result is similar to that reported by Kizys and Pierdzioch (2011).

Examining asymmetric conditional correlations between the US and European stock markets during the US subprime crisis and the European debt crisis, Kenourgios (2014) found contagion across these markets during both crises. Papavassiliou (2014) examined correlation between Greek sovereign stocks and bonds in order to study contagion of the Greek crisis. Using a DCC model, the author concluded that correlation between sovereign stocks and bonds returns increased significantly during the Greek debt crisis, pointing to the presence of a contagion effect cross the two markets. Similarly, Missio and Watzka (2011) used a DCC model to examine the dynamics of correlations between Greek sovereign returns and sovereign returns of the Eurozone countries. The authors found financial contagion across the Belgian, Italian, Portuguese and Spanish sovereign debt markets. Afonso et al. (2012) examined whether sovereign returns and credit default swaps (CDS) spreads in a given country react to the sovereign ratings of other countries. They point out to a contagion phenomenon, in particular from the lowest-rated countries to the highest-rated countries.

These mixed results reported by contagion literature are typical, as they are not unique to the Eurozone debt crisis. Indeed, such controversies stem from the different definitions given to contagion, the used measurement methods and the choice of the crisis periods.

\section{MATERIAL AND METHODS}

\section{Methodology}

In order to overcome the shortcomings of the Constant Conditional Correlation-Generalized Autoregressive Conditional Heteroscedasticity (CCC-GARCH) model, Engle and Sheppard (2001), Engle (2002) and Tse and Tsui (2002) proposed the DCC-GARCH model, which is an original dynamic estimation of conditional correlations in Multivariate GARCH models. Their specification allows for a time varying matrix because the DCC-GARCH introduces equations describing the evolution of correlation coefficients in time.

Therefore, in order to measure dynamic conditional correlations, we apply the DCCGARCH model proposed by Engle (2002). The multivariate model is defined as follows: 
where:

$$
X_{t}=\mu_{t}+\epsilon_{t}
$$

$$
\begin{gathered}
X_{t}=\left(X_{1 t}, X_{2 t}, \ldots \ldots . ., X_{N t}\right)-\text { is the vector of past observations; } \\
\mu_{t}=\left(\mu_{1 t}, \ldots, \mu_{N t}\right)-\text { is the vector of conditional returns } \\
\epsilon_{t}=\left(\epsilon_{1 t}, \epsilon_{2 t}, \ldots \ldots \ldots . ., \epsilon_{N t}\right)-\text { is the vector of standardised residuals. }
\end{gathered}
$$

The parameters of the DCC model are estimated using the maximum likelihood method introduced by Bollerslev and Wooldridge (1992). This allows to obtain for each variable, variance and conditional covariance.

\section{Data and Descriptive Statistics}

In this study, we examine 7 Eurozone stock indices: Belgium (BEL20), Spain (IBEX35), France (CAC40), Greece (Athex Composite Index), Ireland ( ISEQ overall price), Italy (FTSE MIB) and Portugal (PSI20). The study period stretches between 01/01/2004 and $12 / 31 / 2012$ and includes 2.348 daily observations for each index. Stock indices series are divided into 3 segments, representing 3 distinct sub-periods. The first period is denoted the stable period, which spreads from 01/01/2004 to 07/31/2007, totaling 934 observations. The second period is the subprime crisis period, which begins with the explosion of the real estate bubble on 08/01//2007, ends on 12/07/2009, and includes 614 observations. The third sub-period is the European debt crisis period, which starts on 12/08/2009 (date of downgrading the Greek debt to the speculative category by Fitch) and ends on $12 / 31 / 2012$ and includes 800 observations. Since the period preceding the European debt crisis is also a crisis period, it was necessary to divide the total period of the study into three sub-periods. The aim is to obtain a clear stable period to be compared to the European sovereign debt crisis period. Conventionally and in order to eliminate the unit root present in all indices series, we calculate stock returns as the first difference of the natural log of each stock-price index and the returns are expressed in percentage.

Table 1 reports the descriptive statistics of the daily stock returns series across the total period and the three sub-periods. The standard deviations reported in Panel A present a measure of risk during the total study period. They indicate that the Greek market is the riskiest stock market of all the markets of the sample. Skewness is different from 0 , indicating asymmetry for all the series. Moreover, all returns distributions show a statistically significant Kurtosis greater than 3 , indicating that these distributions dispose of thicker tails than the normal distribution and that they are leptokurtic.

The normality hypothesis of stock returns series is also rejected by the Jarque-Bera test, whose coefficients exceed the critical values, rejecting thus the null hypothesis of normality for the returns series. The ADF (Augmented Dickey-Fuller) and PP (Phillip-Peron) tests, applied to the returns series, are significant at the $1 \%$ level, allowing us to reject the null hypothesis of the presence of a unit root, against the alternative hypothesis of stationarity of all returns series. All Ljung-Box test statistics for the returns series and the squared returns series are significant at the $1 \%$ level. Such statistics indicate the presence of first and second order serial auto-correlation. The existence of the latter implies the presence of a linear dependence and a nonlinear dependence (heteroscedasticity) between returns. This reflects the imperfection of the studied stock markets and attests for the presence of a clustering volatility phenomenon. 
The descriptive statistics of the stock returns series during the three sub-periods are presented in Panels B, C and D. First, we notice that the means of stock market returns have considerably dropped during the two crises periods compared to the stable period. These means are negative for all series during the subprime crisis period. With the exception of the Irish stock returns, the negative means persisted for all returns during the European debt crisis sub-period. The standard deviations of stock returns series are higher during the two crises periods, reflecting thus an increase in stock market volatility during these periods. It is important to note that increase in volatility is greater during the subprime crisis for all returns series, with the exception of the Greek market index.

Table 1. Descriptive statistics of the returns series for the full period $(1 / 1 / 2004-12 / 31 / 2012)$

\begin{tabular}{|c|c|c|c|c|c|c|c|}
\hline \multicolumn{8}{|c|}{ Panel A: The full period: $1 / 1 / 2004-12 / 31 / 2012$} \\
\hline Statistics & ATHEX & BEL20 & CAC40 & FTSEMIB & IBEX35 & ISEQ & PSI20 \\
\hline Mean & 908 & 0.0 & 84 & -0.02 & 0.002045 & -0.015786 & -0.007107 \\
\hline Maximum & 13.43108 & 9.221261 & 10.59459 & 10.87425 & 13.48364 & 9.733092 & 10.19592 \\
\hline Minimum & 04 & & 37 & 92 & -9. & & 918 \\
\hline Std. Dev. & 1.802965 & 1.299611 & & & 1.51 & & 156 \\
\hline Skew & & & & & & 134 & 319 \\
\hline Kurtc & & 71 & & & 70 & 158 & 373 \\
\hline Jarque- & 1933.011* & 4451 & 4951.825* & $3729.624 *$ & 5572.309* & 6047.482* & $.89 *$ \\
\hline LB Q & & & $1 *$ & 66.7 & $54.3^{*}$ & $82.1^{*}$ & \\
\hline $\mathrm{LB} \mathrm{Q}^{2}(24)$ & 5* & $9 *$ & 214 & 6* & $1418^{*}$ & $2888.5^{*}$ & $1534.4^{*}$ \\
\hline ADF & $* * *$ & $-46.512 * * *$ & $0 * * *$ & $-47.397 * * *$ & $6 * * *$ & $8 * * *$ & $9 * * *$ \\
\hline סת & & $-46.474 *$ & $-50.475^{*}$ & $-47.398 *$ & $-47.034 *$ & $-45.147^{*}$ & \\
\hline \multicolumn{8}{|c|}{ Panel B: Pre-crisis period: 1/1/2004-7/31/2007 } \\
\hline tin & 99 & 0.079854 & 0.0606 & 0.050 & 0.078408 & & \\
\hline Std. Dev. & 4818 & 0.738437 & 0.841369 & 0.739597 & 0.798476 & 0.86 & 01 \\
\hline \multicolumn{8}{|c|}{ Panel C: Period of Subprime-crisis: 8/1/2007 - 12/7//2009 } \\
\hline Mean & -0.125504 & -0.076845 & -0.050020 & -0.075709 & -0.011922 & -0.13 & 2304 \\
\hline Std. Dev. & 2.139260 & 1.876056 & 2.037556 & 2.048038 & 1.977444 & 2.486660 & 1.610522 \\
\hline \multicolumn{8}{|c|}{ Panel D: Period of European sovereign debt crisis: 12/8/2009 - 12/31/2012 } \\
\hline & -0 . & -0.00 & -0.005 & -0.043312 & -0.051653 & 970 & \\
\hline Std. Dev. & 2.340983 & 1.294269 & 1.520884 & 1.807983 & 1.774582 & 1.357814 & 1.350111 \\
\hline
\end{tabular}

Notes: ***and * denote statistical significance at the $1 \%$ and $10 \%$ respectively; LB shows Ljung-Box statistics Source: own study.

\section{RESULTS AND DISCUSSION}

\section{The DCC Model and Estimation Results}

The results reported in Table 2 show that the GARCH conditional variances are positive and significant at the $1 \%$ level during the full period, as well as during the three substudy periods. These results indicate that the use of the $\mathrm{GARCH}$ process is adequate, meaning that market volatility varies over time and confirms the presence of conditional heteroscedasticity in the returns series. 
This shows that conditional variances of the returns series depend on their past observations as well as on past shocks highlighting the volatility of the market. However, the results point to some differences in the in short- and long-term persistence of the ARCH and GARCH effects. Indeed, unlike the long-term persistence $\beta$, the short-term persistence measured by $\alpha$ is low in most conditional variance equations.

Table 2. Bivariate DCC-GARCH model estimates

\begin{tabular}{|c|c|c|c|c|c|c|}
\hline \multicolumn{7}{|c|}{ Panel A: Full Period } \\
\hline Par. & ATHEX-BEL20 & ATHEX-CAC4O & ATHEX-FTSEMIB & ATHEX-IBEX35 & ATHEX-ISEQ & ATHEX-PSI20 \\
\hline$\alpha(1)$ & $0.097 * * *$ & $0.097^{* * *}$ & $0.097^{* * *}$ & $0.097^{* * *}$ & $0.097 * * *$ & $0.097 * * *$ \\
\hline$\alpha(2)$ & $0.124 * * *$ & $0.107^{* * *}$ & $0.110 * * *$ & $0.127^{* * *}$ & $0.114 * * *$ & $0.143 * * *$ \\
\hline$\beta(1)$ & $0.904^{* * *}$ & $0.904^{* * *}$ & $0.904^{* * *}$ & $0.904^{* * *}$ & $0.904^{* * *}$ & $0.904 * * *$ \\
\hline$\beta(2)$ & $0.864 * * *$ & $0.882 * * *$ & $0.886 * * *$ & $0.866 * * *$ & $0.880 * * *$ & $0.855 * * *$ \\
\hline$\theta_{1}$ & $0.015^{* * *}$ & $0.019 * * *$ & $0.015^{* * *}$ & $0.014 * * *$ & $0.034 * * *$ & $0.020 * * *$ \\
\hline$\theta_{2}$ & $0.978^{* * *}$ & $0.973^{* * *}$ & $0.980^{* * *}$ & $0.980^{* * *}$ & $0.927^{* * *}$ & $0.971 * * *$ \\
\hline \multicolumn{7}{|c|}{ Panel B: pre-crisis period } \\
\hline$\alpha(1)$ & $0.098 * * *$ & $0.098 * * *$ & $0.098 * * *$ & $0.098 * * *$ & $0.098 * * *$ & $0.098 * * *$ \\
\hline$\alpha(2)$ & $0.151^{* * *}$ & $0.081 * * *$ & $0.116^{* * *}$ & $0.150 * *$ & $0.156 * * *$ & $0.130 * * *$ \\
\hline$\beta(1)$ & $0.837 * * *$ & $0.837 * * *$ & $0.837 * * *$ & $0.837 * * *$ & $0.837 * * *$ & $0.837 * * *$ \\
\hline$\beta(2)$ & $0.747^{* * *}$ & $0.841 * * *$ & $0.779 * * *$ & $0.715^{* * *}$ & $0.745^{* * *}$ & $0.774 * * *$ \\
\hline$\theta_{1}$ & 0.030 & $0.030 * *$ & $0.026 * *$ & 0.017 & $0.072^{* * *}$ & 0.014 \\
\hline$\theta_{2}$ & $0.884 * * *$ & $0.920 * * *$ & $0.919 * * *$ & $0.940 * * *$ & $0.830 * * *$ & $0.943 * * *$ \\
\hline \multicolumn{7}{|c|}{ Panel C: Subprime Crisis period } \\
\hline$\alpha(1)$ & $0.146^{* * *}$ & $0.146 * * *$ & $0.146^{* * *}$ & $0.146^{* * *}$ & $0.146 * * *$ & $0.146 * * *$ \\
\hline$\alpha(2)$ & $0.143 * * *$ & $0.113^{* * *}$ & $0.123 * * *$ & $0.128 * * *$ & $0.106 * * *$ & $0.183^{* * *}$ \\
\hline$\beta(1)$ & $0.849 * * *$ & $0.849 * * *$ & $0.849 * * *$ & $0.849 * * *$ & $0.849 * * *$ & $0.849 * * *$ \\
\hline$\beta(2)$ & $0.815^{* * *}$ & $0.867 * * *$ & $0.861 * * *$ & $0.844 * * *$ & $0.863^{* * *}$ & $0.792 * * *$ \\
\hline$\theta_{1}$ & $0.048^{*}$ & 0.023 & $0.067^{*}$ & $0.015^{*}$ & 0.061 & $0.082 * *$ \\
\hline$\theta_{2}$ & $0.809 * * *$ & $0.824 * * *$ & $0.740 * * *$ & $0.971^{* * *}$ & $0.806 * * *$ & $0.467 * *$ \\
\hline \multicolumn{7}{|c|}{ Panel D: European sovereign debt crisis period } \\
\hline$\alpha(1)$ & $0.073 * * *$ & $0.073 * * *$ & $0.073^{* * *}$ & $0.073^{* * *}$ & $0.073 * * *$ & $0.073 * * *$ \\
\hline$\alpha(2)$ & $0.101 * * *$ & $0.124 * * *$ & $0.104^{* * *}$ & $0.118^{* * *}$ & $0.117^{* * *}$ & $0.152 * * *$ \\
\hline$\beta(1)$ & $0.877^{* * *}$ & $0.877^{* * *}$ & $0.877^{* * *}$ & $0.877^{* * *}$ & $0.877^{* * *}$ & $0.877^{* * *}$ \\
\hline$\beta(2)$ & $0.863^{* *}$ & $0.847^{* * *}$ & $0.876^{* * *}$ & $0.863 * * *$ & $0.846 * * *$ & $0.809 * * *$ \\
\hline$\theta_{1}$ & $0.010^{*}$ & $0.016^{*}$ & $0.011 * *$ & $0.013 * *$ & 0.013 & $0.025 * *$ \\
\hline$\theta_{2}$ & $0.982 * * *$ & $0.970 * * *$ & $0.986 * * *$ & $0.981 * * *$ & $0.971 * * *$ & $0.962 * * *$ \\
\hline
\end{tabular}

Notes: $* * *, * *, *$ denote statistical significance at the $1 \%, 5 \%$ et $10 \%$ respectively

Source: own study.

Our results show that $\alpha$ (the error parameter of the GARCH model, which measures reaction of conditional volatility to market shocks), of the Belgian, Italian and Portuguese stock market returns, is higher during the subprime crisis. Its relatively high value during the first crisis period indicates that volatility of these indices is more sensitive to market events during the subprime crisis than during the sovereign debt crisis period or during the stable period. However, conditional volatility of the two Spanish and Irish indices reacts more to market shocks during the stable period than during the two crises periods. On the other hand, we notice that the short-term persistence of the French and Irish stock 
market volatility during the debt crisis sub-period is higher than that during the subprime crisis sub-period. Furthermore, the results of the autoregressive coefficients of volatility $\beta$, which measures persistence of conditional volatility to different market events, are higher during the two crises periods than those during the stable period. In this regard, Alexander and Lazar (2009) argue that when $\beta$ is relatively high, volatility takes longer to disappear. $\theta_{1}$ and $\theta_{2}$ of the bivariate DCC-GARCH model during the full period are significant at the $1 \%$ level, indicating that the impact of lagged shocks and the impact of lagged dynamic correlations on dynamic conditional correlations are highly significant. These results support the dynamic conditional correlations model and allow us to reject the hypothesis of constant correlation between returns series.

Figure 1 shows the dynamic conditional correlations of the Greek stock index and the six stock indices of our sample. Noticeably, correlation trends alternate between bull and bear phases, indicating their dynamic nature.
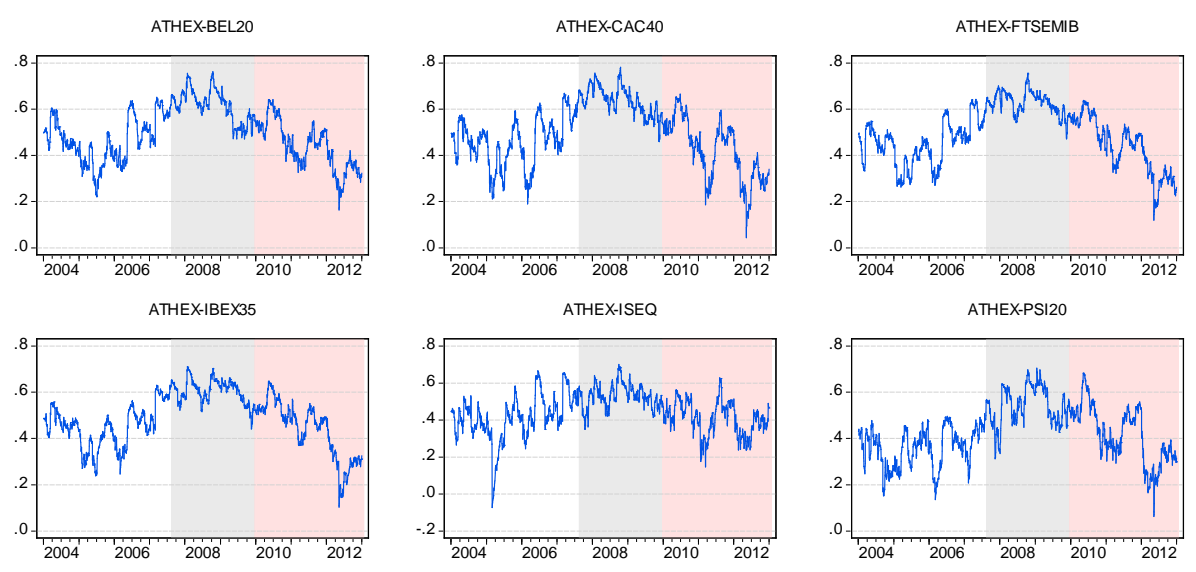

Figure 1. Dynamic conditional correlations during the full period Source: own study.

Although there was a slight increase in correlation beginning in the second quarter of 2006, the latter varied between 3 and $4.7 \%$ on average during the stable period. However, following the outbreak of the subprime crisis, we notice an upward trend of all correlation pairs. The latter rose to an average of $6.5 \%$ and peaked in the third quarter of 2008 . These peaks are higher after the collapse of Lehman Brothers in September 2008, triggering the crisis. During the European sovereign debt crisis period, dynamic correlations reached an average of $4 \%$. We can distinguish two upward phases during this period: the first took place following the Greek crisis at the end of 2009 and the second following the worsening of the debt crisis in the summer of 2011. However, although there are upward trends, average correlations are lower than those during the subprime crisis period.

\section{Contagion Test}

In order to determine the presence of contagion effects generated by the subprime crisis and the European sovereign debt crisis, we follow Forbes and Rigobon (2002) who define contagion as a significant increase in the relationships between markets after a country shock. Moreover, in the absence of a significant trend of co-movements during 
crisis periods, the term interdependence is used to describe dynamics between markets. We test the presence of contagion across the Eurozone stock markets by examining the adjusted dynamic conditional correlations in order to test for the presence of a shift contagion in the sense of Forbes and Rigobon (2002).

Let $X_{t}$ and $Y_{t}$ be two stock returns series such that:

$$
Y_{t}=\alpha+\beta X_{t}+\epsilon_{t}
$$

Where $\alpha$ and $\beta$ are constants and $\epsilon_{t}$ represents the error terms.

According to Forbes and Rigobon (2002), the correlation coefficient $\rho$ between $X_{t}$ and $Y_{t}$ is adjusted by the following:

$$
\rho^{*}=\frac{\rho}{\sqrt{1+\delta\left[1-\rho^{2}\right]}}
$$

With $\delta=\sigma_{x}^{c} / \sigma_{x}^{t}-1$, where $\delta$ measures the relative increase in the volatility of $x_{t}$ cross the two crises and stable periods and $\sigma_{x}^{c}$ and $\sigma_{x}^{t}$ are the conditional variances of the stochastic variable $X_{t}$ respectively during the crisis period and the stable period.

In our study, the variable $X_{t}$ represents the daily returns of the Greek stock index and the variable $Y_{t}$ represents the daily returns of the other stock indexes of our sample. We use the following two alternative hypotheses to test the significance of the increase in the adjusted and unadjusted correlation coefficients:

$$
\left\{\begin{array}{l}
H_{0}: \rho^{*}{ }_{c}=\rho^{*}{ }_{t} \\
H_{1}: \rho^{*}{ }_{c}>\rho^{*}{ }_{t}
\end{array}\right.
$$

Accepting the null hypothesis $H_{0}$ means that correlation between the two markets does not increase significantly across the two sub-periods. In this case, we conclude to a simple interdependence between markets and not a shift contagion.

Accepting the alternative hypothesis $H_{1}$ means that correlation between the two markets increased significantly across the two sub-periods, proving the presence of a shift contagion.

We use the t-Student test presented by Collins and Biekpe (2003) to examine these hypotheses. The test is given by:

$$
t=\left(\rho^{*}{ }_{c}-\rho^{*}{ }_{t}\right) \sqrt{\frac{n_{c}+n_{t}-4}{1-\left(\rho^{*}{ }^{-} \rho^{*}\right)^{2}}}
$$

$\mathrm{t}$ is distributed with $\left(n_{1}+n_{2}-4\right)$ degrees of freedom, $n_{c}$ and $n_{t}$ are respectively the number of observations during the crises periods and the stable period.

The results of the contagion tests on the subprime crisis and the European sovereign debt crisis are presented in Table 3 below. First, we notice that the dynamic conditional correlations of the Greek stock market and the Eurozone stock markets increased during the subprime crisis period compared to the stable period. Indeed, the t-statistic is significant for all market pairs at the $1 \%$ level, hence we reject the null hypothesis.

Like in Boyer et al. (1999), stock returns' dynamic correlations show upward trends during crises events. This increase comes along an increase in the conditional variances of all European stock markets of our sample. These results are consistent with the literature indicating that conditional correlations tend to increase as conditional variance increases (Martens \& Poon, 2001). This upward trend is confirmed both for unadjusted and adjusted dynamic conditional correlations. Thus, we can conclude to the presence of a contagion 
Table 3. Contagion test results

\begin{tabular}{|c|c|c|c|c|c|c|c|c|c|c|}
\hline \multirow{3}{*}{ Indices } & \multicolumn{5}{|c|}{ Unadjusted conditional correlations } & \multicolumn{5}{|c|}{ Adjusted conditional correlations } \\
\hline & $\begin{array}{l}\text { Pre- } \\
\text { crisis }\end{array}$ & $\begin{array}{c}\text { Subprime } \\
\text { crisis }\end{array}$ & \multirow{2}{*}{$\begin{array}{c}\text { t- } \\
\text { student }\end{array}$} & \multirow{2}{*}{$\begin{array}{l}\text { Change } \\
\text { of mean correlation } \\
\text { coefficients }\end{array}$} & \multirow[t]{2}{*}{ Contagion } & $\begin{array}{l}\text { Pre- } \\
\text { crisis }\end{array}$ & $\begin{array}{c}\text { Subprime } \\
\text { crisis }\end{array}$ & \multirow{2}{*}{$\begin{array}{c}\mathrm{t}- \\
\text { student }\end{array}$} & \multirow{2}{*}{$\begin{array}{c}\text { Change } \\
\text { of mean correlation } \\
\text { coefficients }\end{array}$} & \multirow[t]{2}{*}{ Contagion } \\
\hline & $\rho_{i j}^{t}$ & $\rho_{i j}^{c}$ & & & & $\rho_{i j}^{* t}$ & $\rho_{i j}^{* c}$ & & & \\
\hline BEL20 & 0.465 & 0.642 & $7.07 * * *$ & $38.06 \%$ & Yes & 0.229 & 0.351 & $4.843^{* * *}$ & $53.28 \%$ & Yes \\
\hline CAC40 & 0.458 & 0.668 & $8.45^{* * *}$ & $45.85 \%$ & Yes & 0.225 & 0.373 & $5.901 * * *$ & $65.78 \%$ & Yes \\
\hline FTSEMIB & 0.444 & 0.654 & $8.46^{* * *}$ & $47.30 \%$ & Yes & 0.216 & 0.361 & $5.748^{* * *}$ & $67.13 \%$ & Yes \\
\hline IBEX35 & 0.449 & 0.629 & $7.19 * * *$ & $40.09 \%$ & Yes & 0.219 & 0.341 & $4.800 * * *$ & $55.71 \%$ & Yes \\
\hline ISEQ & 0.401 & 0.581 & $7.16^{* * *}$ & $44.89 \%$ & Yes & 0.192 & 0.304 & $4.417^{* * *}$ & $58.33 \%$ & Yes \\
\hline PSI20 & 0.331 & 0.589 & $10.50^{* * *}$ & $77.95 \%$ & Yes & 0.155 & 0.310 & $6.17^{* * *}$ & $100.00 \%$ & Yes \\
\hline \multirow{3}{*}{ Indices } & \multicolumn{5}{|c|}{ Unadjusted conditional correlations } & \multicolumn{5}{|c|}{ Adjusted conditional correlations } \\
\hline & $\begin{array}{l}\text { Pre- } \\
\text { crisis }\end{array}$ & $\begin{array}{l}\text { Sovereign } \\
\text { debt crisis }\end{array}$ & \multirow{2}{*}{$\begin{array}{c}\mathrm{t}- \\
\text { student }\end{array}$} & \multirow{2}{*}{$\begin{array}{c}\text { Change } \\
\text { of mean correlation } \\
\text { coefficients }\end{array}$} & \multirow{2}{*}{ Contagion } & $\begin{array}{l}\text { Pre- } \\
\text { crisis }\end{array}$ & $\begin{array}{l}\text { Sovereign } \\
\text { debt crisis }\end{array}$ & \multirow{2}{*}{$\begin{array}{c}t- \\
\text { student }\end{array}$} & \multirow{2}{*}{$\begin{array}{c}\text { Change } \\
\text { of mean correlation } \\
\text { coefficients }\end{array}$} & \multirow{2}{*}{ Contagion } \\
\hline & $\rho_{i j}^{t}$ & $\rho_{i j}^{c}$ & & & & $\rho_{i j}^{* t}$ & $\rho_{i j}^{* c}$ & & & \\
\hline BEL20 & 0.465 & 0.413 & -2.186 & $-11.18 \%$ & No & 0.211 & 0.183 & -1.167 & $-13.27 \%$ & No \\
\hline CAC40 & 0.458 & 0.397 & -2.552 & $-13.32 \%$ & No & 0.207 & 0.175 & -1.342 & $-15.46 \%$ & No \\
\hline FTSEMIB & 0.444 & 0.418 & -1.052 & $-5.86 \%$ & No & 0.199 & 0.186 & -0.555 & $-6.53 \%$ & No \\
\hline IBEX35 & 0.449 & 0.414 & -1.488 & $-7.80 \%$ & No & 0.202 & 0.183 & -0.786 & $-9.41 \%$ & No \\
\hline ISEQ & 0.401 & 0.392 & -0.377 & $-2.24 \%$ & No & 0.177 & 0.172 & -0.191 & $-2.82 \%$ & No \\
\hline PSI20 & 0.331 & 0.415 & $3.533^{* * *}$ & $25.38 \%$ & Yes & 0.142 & 0.184 & $1.743^{* *}$ & $29.58 \%$ & Yes \\
\hline
\end{tabular}

Note: t-student's critical values are (2.326), (1.645) and (1.282) at the $1 \%, 5 \%$ and $10 \%$ levels respectively;

*** and ${ }^{* *}$ denote statistical significance at the $1 \%$ and $5 \%$ levels respectively.

Source: own study. 
effect generated by the subprime crisis across the Greek stock market and the other markets of our sample. This contagion can be described as shift contagion in the sense of Forbes and Rigobon (2002).

Our results are consistent with those of Hwang et al. (2010) who point to the significant impact of the subprime crisis on most international stock markets. However, examining the contagion effects generated by the European sovereign debt crisis shows that only the dynamic conditional correlations of the Greek stock market and the Portuguese stock market have increased during the European debt crisis period compared to the stable period. This increase is reflected by a t-statistic statistically significant at the $1 \%$ level. These results are in line with those reported by Horta (2012) and Kizys and Pierdzioch (2011). The fundamental trade and financial relationships between Greece and Portugal, the effect of market participants' herding behaviour explained by financial panic after the Greek debt crisis, may explain shift contagion across Greece and Portugal, as estimated by the DCC model. Indeed, a few months after the Greek crisis, downgrading the Portuguese debt by Standard \& Poor's in April 2010 raised concerns about the long-existing fundamental problems of the country. Portugal was then closely monitored by investors, leading to a sudden drop in financing packages and the worsening of the country's real problems. This context of widespread mistrust was reflected in an increased volatility of the Portuguese stock market and a collapse of stock prices. However, the results for the other market pairs are insignificant. Therefore, we fail to reject the null hypothesis assuming that dynamic correlations did not increase during the European sovereign debt crisis period compared to the stable period. With these results, we can conclude that the debt crisis generated a contagion effect from the Greek stock market to the Portuguese stock market. A contagion that can be described as shift contagion in the sense of Forbes and Rigobon (2002). However, the relationship which defines the Greek stock market and the other markets of the sample cannot be described as contagion but only interdependence.

\section{CONCLUSIONS}

Contagion across the Eurozone stock markets is attracting the growing interest of analysts and researchers. Our study examined the relationship between the Greek stock market and six Eurozone stock markets. We applied the bivariate DCC-GARCH model to test this relationship over the 2004-2012 period, divided into two crises periods: the subprime crisis and the European debt crisis. Our results indicate that the subprime crisis generated a contagion effect on all market pairs. On the other hand, during the European debt crisis period, the relationship between the Greek market and the Eurozone stock markets is described as a simple interdependence, an exception is the Portuguese market. However, our results indicate that the dynamic correlations of the Greek and Portuguese markets changed during the second crisis period, suggesting the presence of a contagion effect between these two markets. Indeed, weakened by its public debt, as well as by a decrease of its rating, Portugal was considered the second 'weak link' in the Eurozone. Since then, the country went through a wave of fear that Portugal was increasingly being contaminated by the Greek crisis. Portugal then underwent a speculation transfer phenomenon in its market (Costa et al., 2016). However, our results point to a shift contagion across the Greek and the Portuguese stock markets during this period. 
The obtained results are useful for investors, in particular for their portfolio diversification strategies. They are also useful for the monetary and financial authorities in their efforts to absorb shocks resulting from crises. Indeed, good understanding of contagion effects is an important step towards designing portfolios trading, hedging and optimisation strategies. Moreover, authorities' efforts during a financial crisis in a given country will only be effective if the relationships between the two countries are significantly different before and after the crisis. If, however, no contagion is detected, the efforts will have very limited effects since financing problems in this case result mainly from the country's fundamental economic and budgetary problems.

Finally, we believe that the measures of contagion effects following the valuation of countries induced by the massive negative sovereign rating signals during the crisis period would also be interesting to study. Our proposed methods might also be applicable to this kind of contagion type and for contagions effects across European stock market returns.

\section{REFERENCES}

Afonso, A., Furceri, D., \& Gomes, P. (2012). Sovereign credit rating and financial markets linkages, application to European data. Journal of International Money and Finance, 31(3), 606-638.

Alexander, C., \& Lazar, E. (2009). Modelling regime-specific stock price volatility. Oxford Bulletin of Economics and Statistics, 71(6), 761-797.

Andenmatten, S., \& Brill, F. (2011). Measuring comovements of CDS premia during the Greek debt crisis, Discussion Paper, No. 11-04. University of Bern, Department of Economics.

Arezki, R, Candelon, B., \& Sy, A.V.R. (2011). Sovereign rating news and financial market spillovers, evidence from European debt crisis. IMF working papers.

Bartram, S., Taylor, S.J., \& Wang, Y. (2007). The euro and European financial market dependence». Journal of Banking and Finance, 51(5), 1461-1481.

Bekaert, G., Ehrmann, M., Fratzscher, M., \& Mehl, A. (2014). The global crisis and equity market contagion. The Journal of Finance, 69, 2597-2649.

Bollerslev, T., \& Wooldridge, J.M. (1992). Quasi-maximum likelihood estimation and inference in dynamic models with time varying covariances. Econometric Reviews, 11, 143-172.

Boyer, B.H., Gibson, M.S., \& Loretan, M. (1999). Pitfalls in tests for changes in correlations. Federal Reserve Boars, IFS Discussion Paper, 597R.

Briere, M., Chapelle, A., \& Szafarz, A. (2012). No contagion, only globalization and flight to quality ». Journal of International Money and Finance, 31(6), 1729-1744.

Caporin, M., Pelizzon, L., Ravazzolo, F., \& Rigobon, R. (2013). Measuring sovereign contagion in Europe». NBER Working Paper 18741.

Claeys, P., \& Vasicek, B. (2014). Measuring bilateral spillover and testing contagion on sovereign bond markets in Europe. Journal of Banking \& Finance, 151-165.

Collins, D., \& Biekpe, N. (2003). Contagion: a fear for African equity markets?. Journal of Economics and Business, 55, 285-297.

Connor, G., \& Suurlaht, A. (2013). Dynamic stock market covariances in the Eurozone. Journal of International Money and Finance, 37, 353-370.

Costa, L., Martins, N.O., \& De Oliveira, F.G. (2016). Portugal's bailout and the crisis of the European Union from a capability perspective. Cambridge Journal of Economics, 40(6), 1479-1496. 
Ehrmann, M., \& Fratzscher, M. (2016). Euro area government bonds-Fragmentation and contagion during the sovereign debt crisis. Journal of International Money and Finance, 70, 26-44.

Engle, R.F., \& Sheppard, K. (2001). Theoretical and empirical properties of dynamic conditional correlation multivariate GARCH. NBER Working Paper 8554.

Engle, R.F. (2002). Dynamic conditional correlation: A simple class of multivariate generalized autoregressive conditional heteroscedasticity models. Journal of Business and Economic Statistics, 20(3), 339-350.

Forbes, K., \& Rigobon, R. (2002). No contagion, only interdependence: Measuring stock market comovements. Journal of Finance, 57(5), 2223-2261.

Fratzscher, M. (2002). Financial market integration in Europe: on the effect of EMU on stock markets. International Journal of Finance and Economics, 7(3), 165-193.

Horta, P. (2012). Contagion effect in the European NYSE Euronext stock market in the context of the 2010 sovereign debt crisis. CEFAGEUE Working paper.

Hwang, I., In, F.H. \& Kim, T.S. (2010). Contagion effects of the U.S. subprime crisis on international stock markets, Finance and Corporate Governance Conference Paper.

Kalbaska, A., \& Gatkowski, M. (2012). Eurozone sovereign contagion: evidence from the CDS market (2005-2010). Journal of Economic Behavior and Organization, 83(3), 657-673.

Kerourgios, D. (2014). On financial contagion and implied market volatility. International Review of financial analysis, 34, 21-30.

Kizys, R., \& Pierdzioch, C. (2011). The financial crisis and the stock markets of the CEE countries. Czech Journal of Economics and Finance, 61(2), 153-172.

Martens, M., \& Poon, S.H. (2001). Returns synchronization and daily correlation dynamics between international stock markets. Journal of Banking and Finance, 25, 1805-1827.

Metiu, N. (2012). Sovereign risk contagion in the Eurozone. Economics Letters, 117(1), 35-38.

Missio, S., \& Watzka, S. (2011). Financial contagion and the European debt crisis, CESifo, Munich, Germany. Working Paper 3554.

Papavassiliou, V.G. (2014). Cross-asset contagion in times of stress. Journal of Economics and Business, 76, 133-139.

Papavassiliou, V.G. (2014). Financial contagion during the European sovereign debt crisis: a selective literature review. Crisis Observatory, Research Paper, 11.

Ray, M. (2015). Eurozone debt crisis, Encyclopædia Britannica. Retrieved on August 20,2018 from https://www.britannica.com/topic/European-Union/The-euro-zone-debt-crisis).

Samitas, A., \& Tsakalos, I. (2013). How can a small country affect the European economy, The Greek contagion phenomenon. Journal of International Financial Markets, Institutions and Money, 25(6), 18-32.

Savva, C.S. (2009). International stock markets interactions and conditional correlations. Journal of International Financial Markets, Institutions and Money, 19(4), 645-661.

Smeets, D. (2016). Financial contagion during the European sovereign debt crisis. Journal of Economic and Financial Studies, 4(2), 46-59.

Trabelsi, M.A. (2012). The impact of the sovereign debt crisis on the Eurozone countries. ProcediaSocial and Behavioral Sciences, 62, 424-430. 


\section{Authors}

The contribution share of authors is equal and amounted to $50 \%$ each of them.

\section{Mohamed Ali Trabelsi}

Full Professor in Quantitative Methods, Head of the Department of Quantitative Methods \& Director of Econometrics Applied to Finance Laboratory.

Correspondence to: Prof. Mohamed Ali Trabelsi, PhD, University of Tunis El Manar, Faculty of Economics and Management of Tunis, Campus universitaire Farhat Hached, 2092, Tunisia, e-mail: medali.trabelsi@fsegt.utm.tn or daly1704@yahoo.fr

\section{Salma Hmida}

Doctor in Finance and Researcher in the Laboratory of Econometrics Applied to Finance.

Correspondence to: Dr. Salma Hmida, University of Tunis El Manar, Faculty of Economics and Management of Tunis, Campus universitaire Farhat Hached, 2092, Tunisia, e-mail: hmidasoulaima@gmail.com

\section{Acknowledgements and Financial Disclosure}

The authors would like to thank the anonymous referees for their useful comments which contributed to increase the value of this article; they would also like to express their gratitude to the Editor and Dr. Piotr Stanek for their valuable comments of the draft version of this article.

\section{Copyright and License}

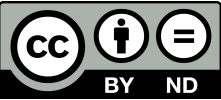

This article is published under the terms of the Creative Commons

Attribution - NoDerivs (CC BY-ND 4.0) License

http://creativecommons.org/licenses/by-nd/4.0/

\section{Published by the Centre for Strategic and International Entrepreneurship - Krakow, Poland}

Ministry of Science The copyediting and proofreading of articles in English is financed in the framework and Higher Education of contract No. 845/P-DUN/2018 by the Ministry of Science and Higher Education of 
